\title{
Psykiatrisk epidemiologi i Norge - et historisk tilbakeblikk
}

\author{
Odd Steffen Dalgard \\ Institutt for allmennmedisin og samfunnsmedisin, Universitetet $i$ Oslo \\ Korrespondanse: Odd Steffen Dalgard, Thomas Heftyes gt. 29, 0264 Oslo
}

\begin{abstract}
SAMMENDRAG
Artikkelen beskriver utviklingen innen psykiatrisk epidemiologi i Norge, med vekt på de ulike faser når det gjelder problemstillinger og metodikk. De første undersøkelser fant sted i første del av det 19. århundre som ledd i planleggingen av de første psykiatriske sykehus, og besto av enkle opptellinger av landets sinnssyke. Den neste fasen var knyttet til opprettelsen av et landsomfattende Sentralregister for sinnssyke i 1936, som ga grunnlag for en rekke epidemiologiske undersøkelser av forholdet mellom innleggelse for alvorlig sinnlidelse og sosiodemografiske variable. Disse undersøkelser ble etter hvert supplert med flere undersøkelser av forekomsten av psykiske lidelser i primærhelsetjenesten. De senere tiårene har vært preget av psykiatriske befolkningsundersøkelser, med basis i strukturerte spørreskjema eller standardiserte kliniske intervjuer.
\end{abstract}

Dalgard OS. Psychiatric epidemiology in Norway - a historic overview. Nor J Epidemiol 2002; 12 (3): $163-172$.

\section{ENGLISH SUMMARY}

The article gives a historic overview of the development of psychiatric epidemiology in Norway from the first part of the $19^{\text {th }}$ century up to now. The first studies were simple counting of insane and mentally defective people in the community, as part of the planning of the first psychiatric hospitals. A breakthrough of psychiatric epidemiology in Norway was linked to the establishment of a National Register of Insane in 1936, which led to a number of studies about the relationship between admission to psychiatric hospital and socio-demographic variables. This type of data was later supplemented with data from the primary health services, and a number of studies of the prevalence of psychiatric disorders in primary health care were carried out. In the later years, population surveys, based on structured questionnaires or standardised clinical interviews have been predominant.

\section{INNLEDNING}

Fra de første opptellinger av sinnssyke i Norge, til dagens mer avanserte epidemiologiske undersøkelser, har det skjedd en dramatisk utvikling både når det gjelder diagnostikk av psykiske lidelser, undersøkelsesmetoder, og analyse av data. Det har også skjedd en betydelig utvikling når det gjelder definering og måling av sosiale og psykososiale faktorer som kan være knyttet til psykiske lidelser, som årsaksfaktorer og/eller som konsekvenser av lidelser. Fra rent deskriptive studier av de alvorligste sinnslidelser, har utviklingen gått $\mathrm{i}$ retning av analytiske studier, der ulike risiko- og beskyttelsesfaktorer ses $\mathrm{i}$ forhold til et bredt spekter av psykiske lidelser, gjerne innenfor en longitudinell design. Etter hvert har en også fått innslag av eksperimentell epidemiologi, der den epidemiologiske kartlegging danner utgangspunkt for ulike typer intervensjon med påfølgende evaluering. I det følgende vil jeg trekke fram en del eksempler på studier fra de ulike faser av utviklingen av psykiatrisk epidemiologi i Norge. Artikkelen er stort sett begrenset til en omtale av epidemiologiske undersøkelser av alminnelige populasjoner, og omhandler ikke studier av spesielle befolk- ningsgrupper, som tvillinger, militært personell eller spesielle institusjonspopulasjoner, selv om en også her gjør bruk av epidemiologiske metoder. Fremstillingen er inndelt i følgende avsnitt:

- De første tellinger av sinnssyke $i$ samfunnet

- Undersøkelser basert på sykehusinnleggelser

- Undersøkelser hovedsakelig basert på data fra primarleger

- Befolkningsundersøkelser hovedsakelig basert på spørreskjema eller strukturert intervju

- Befolkningsundersøkelser hovedsakelig basert på semistrukturerte eller standardiserte kliniske intervju

\section{DE FØRSTE TELLINGER AV SINNSSYKE I SAMFUNNET}

Etter initiativ fra Kirken ble det i 1824 opprettet en Kongelig Kommisjon med ansvar for opptelling av alle sinnssyke i Norge, slik at en på dette grunnlag kunne planlegge de nødvendige institusjonsplasser. Opptellingen ble utført i 1826 av landets prester, og resultatene ble publisert av professor Frederik Holst i 1828 (1). Neste opptelling av sinnssyke ble gjort i 
1835, som et ledd i den alminnelige folketelling, og en tilsvarende opptelling ble også gjort i 1845 (2). Alt fra første stund var det betydelige problemer knyttet til den diagnostiske inndeling, ikke minst fordi verken prester, og senere heller ikke lærere og andre som deltok i opptellingene, hadde de nødvendige kvalifikasjoner for å skille mellom de ulike kategorier. En opererte da med følgende diagnoser:

Maniaci. Urolige, voldelige, "rasende" ("gale")

Melancholia. Folk med vrangforestillinger (ikke nødvendigvis depressivt farget), men ellers mer eller mindre friske på sinnet

Dementia. Svekkelse av forstandsevnene hos folk som tidligere har vært friske

Idiotia. Mer eller mindre mangelfull utvikling av forstandsevnene fra fødselen av

Spesielt når det gjaldt maniaci, dementia og idiotia hadde undersøkerne vanskelig for å skille, og selv om opptellingskommisjonen kunne foreta visse korreksjoner basert på undersøkernes notater, ble tallene svært usikre som utgangspunkt for diagnostisk inndeling. Når det gjelder det totale antall sinnssyke, var det imidlertid en dramatisk økning fra 1826 til 1835 (henholdvis 1909 og 3576 sinnssyke) mens antallet øket videre til 4290 i 1845 . Den første sterke økningen skyldtes nok hovedsakelig at tallene ved den første tellingen var svært ufullstedige, men Holst mente også at frigivelsen av brennevinsbrenning på denne tid kunne være av betydning. Andelen av sinnssyke var klart større på landet enn i byene, mens den kjønnsvise fordeling svingte fra størst hyppighet blant menn ved de to første opptellinger til størst hyppighet blant kvinner ved de siste opptellinger.

Mens de første opptellinger hovedsakelig ga grunnlag for rent tallmessige oversikter, nedla Ludvig Dahl (reservelæge ved Gaustad Sindssygeasyl) et betydelig arbeid $\mathrm{i}$ en videre analyse av de foreliggende data, der også mulige årsaksfaktorer ble diskutert (3). I utgangspunktet var Dahl skeptisk til undersøkernes diagnoser, og han foretok derfor en validitetsundersøkelse der han selv undersøkte 197 sinnsyke som tidligere var diagnostisert av skolelærere. Han fant da at lærerne særlig hadde hatt vanskelig for å skille mellom "rasende" (en undergruppe av maniaci) og "fjanter etter fødselen" (demente). For å få en mer pålitelig inndeling valgte Dahl å gjøre en forenkling, slik at en fikk bare to grupper: "Erhvervet sinnssykdom" (maniaci, melancholia og dementia) og idiotia. Ved denne inndeling var det meget godt samsvar mellom hans egen inndeling og lærernes. Dahl anvender så denne inndeling på en ny telling av sinnssyke i 1855, og foretar en sammenlikning med de tidligere opptellinger. Han finner da en økning over tid med hensyn til både idiotia og "erhvervet sinnssykdom" som er større enn økningen av landets befolkning. Av særlig interesse er Dahls påpekning av til dels betydelige geografiske forskjeller når det gjelder hyppighet av sinnssykdom. Ved de siste opptellinger, som antas å være de mest pålitelige, finner han størst hyppighet av sinnssykdom, og spesielt av idiotia, i landdistriktene. Når det gjelder de ulike deler av landet, finner han minst hyppighet av "erhvervede sinnssykdommer" på Vestlandet, mens tallene er størst i de indre områder av Sør- og Øst-Norge, og i Finnmark. Når det gjelder idiotia er mønsteret mer uklart. Med hensyn til årsaksforhold, legger Dahl stor vekt på alkoholmisbruk, noe han finner støtte for når han sammenholder den geografiske fordeling av sinnssykdom med Eilert Sundts omtrent samtidige kartlegging av drikkfeldighet. For øvrig legger han stor vekt på onani ("selvbesmittelse") og "nedtrykkende sindsbevægelser", fysiske svekkelsestilstander og uheldig religiøs påvirkning, noe han mener å finne støtte for $\mathrm{i}$ kasuistiske gjennomgåelser. Arv tillegges imidlertid også stor vekt. Selv om Dahls tanker om årsaksforhold til dels kan virke løst fundert, og i stor grad synes å gjenspeile tidens moralske holdninger, representerer hans epidemiologiske undersøkelser et meget verdifullt pionerarbeid innen psykiatrisk forsking i Norge.

\section{UNDERSØKELSER BASERT PÅ SYKEHUSINN- LEGGELSER}

Mens de første opptellinger av sinnssyke utgjorde en viktig del av grunnlaget for opprettelsen av psykiatriske institusjoner, falt det naturlig at den neste fasen av psykiatrisk epidemiologi ble basert på institusjonsinnleggelser. Når det gjelder denne forskingen, var Ørnulv Ødegaard en pioner, og hans arbeid om innleggelser i psykiatriske sykehus blant norske emigranter i Minnesota og i Norge i perioden 1889-1929, er en klassiker innen internasjonal psykiatrisk epidemiologi (4). Hans hovedfunn var at de norske emigrantene i Minnesota hadde en større hyppighet av førstegangsinnleggelser for psykose enn de Amerika-fødte i Minnesota, og også større enn nordmenn i Norge i samme tidsrom. Dette resultat kunne tolkes i to retninger: enten at de norske emigrantene representerte et negativt utvalg med hensyn til psykisk helse (seleksjonshypotesen), eller at disse hadde vært utsatt for særlige påkjenninger (stresshypotesen). Med støtte i kasuistiske gjennomgåelser, kommer Ødegaard til at det med hensyn til schizofreni antakelig er seleksjonsfaktorene som er dominerende, mens stress antakelig spiller en større rolle ved psykoser blant eldre. Når det gjelder seleksjon, antar han at det er flere med schizoid personlighet blant emigrantene enn blant de fastboende, og at dette betinger en løsere tilknytning til familie og venner på fødestedet, samtidig som det kan disponere for schizofreni. Han finner for øvrig at en del av emigrantene var preget av sin psykose allerede før de reiste ut. Når det gjelder stressfaktorer legger han størst vekt på hardt arbeid og fremmed miljø.

Med utgangspunkt i sin forskning omkring innleggelser av sinnssyke, tok Ødegård i 1936 initiativ til opprettelsen av et landsomfattende Sentralregister for innleggelser av sinnssyke pasienter (senere i denne artikkel bare kalt Sentralregisteret). Sentralregisteret, 
som lå på Gaustad sykehus, dekket alle innleggelser for psykose tilbake til 1916, og var det første i verden i sitt slag. Selv om påliteligheten av diagnoser selvfølgelig ble langt sikrere med et slikt register enn ved de tidligere opptellinger av sinnssyke ute i befolkningen, var det knyttet usikkerhet også til pasientregisteret som basis for epidemiologisk forsking. Alle sinnssyke blir jo ikke innlagt i institusjon. Dette var også et problem som Ødegaard selv var opptatt av, og som han tar opp i en egen publikasjon (5). Han kommer der til at innleggelses-statistikken antakelig omfatter de aller fleste med diagnosen schizofreni eller schizofreniform psykose, mens dekningen av affektive psykkoser antakelig er dårligere. Under alle omstendigheter falt ikkepsykotiske sinnslidelser utenfor registeret, slik at det bare kunne gi et bilde av de sykeste innenfor det psykiatriske sykdomspanorama. Men dette er selvfølgelig en meget viktig del, og Sentralregisteret dannet grunnlaget for en lang rekke interessante epidemiologiske undersøkelser. I denne forskingen, og annen forsking basert på sykehusinnleggelser, fokuserte en i første rekke på forholdet mellom psykoser og vanlige sosiodemografiske variable, som migrasjon, utdannelse og yrke, som det var data på i den alminnelige befolkningsstatistikk. En var da særlig interessert i de relative tall for insidens av psykoser, slik det fremkom når en sammenliknet ulike sosiale grupper.

\section{Migrasjon}

Eitinger (6) tok for seg en spesiell gruppe migranter, nemlig flyktninger til Norge i perioden 1946-55, og basert på innleggelser for psykiske lidelser sammenliknet han den psykiatriske morbiditet blant flyktninger i Norge og norskfødte. Han fant da at flyktningene hadde omtrent 10 ganger så stor innleggelseshyppighet for psykose som den norske befolkning, og at det var paranoide tilstander som dominerte blant de psykotiske flyktningene. Ved personlig intervjuing av flyktningepasientene (60 psykoser og 35 nevroser) fant Eitinger at sosial usikkerhet og isolasjon antakelig var en viktig årsaksfaktor ved utviklingen av psykose i denne befolkningsgruppen. Han mente imidlertid også at de påkjenninger som flyktningene hadde vært utsatt for før de kom til Norge var medvirkende til deres dårlige psykiske helse.

Ødegaard (7) og senere Ødegaard og Astrup (8) undersøkte forholdet mellom flytninger innen Norge og førstegangsinnleggelser for psykoser, med utgangspunkt i Sentralregisteret. Deres hovedfunn var at de som hadde flyttet fra sin fødekommune gjennomgående hadde lavere innleggelseshyppighet enn de som ikke hadde flyttet. Et unntak fra dette var Oslo, der de kvinnelige innflyttere hadde en øket innleggelseshyppighet. Med utgangspunkt i journalgjennomgåelser konkluderte forfatterne med at seleksjon snarere enn stress antakelig var årsaken til den gjennomgående lave innleggelseshyppighet hos de som flyttet. Det å flytte var vel forenlig med et godt liv, og flytting var antakelig oftere uttrykk for sosial fremgang enn for et problem. Når det gjelder de høye innleggelsestall for de kvinnelige innflyttere i Oslo, antar forfatterne at dette kan henge sammen med at det er forholdvis mange innflyttede hushjelper i Oslo, og disse er tidligere kjent som en gruppe med særlig høy innleggelseshyppighet. Tolkningen av resultatene er imidlertid vanskelig, da mangelfull tilgang på data ikke gjorde det mulig å kontrollere samtidig for effekten av ulike sosiodemografiske variable.

I en senere undersøkelse over sammenhengen mellom flytninger og funksjonelle psykoser blant folk bosatt i Oslo, kontrollerte Dalgard (9) for en rekke sosiodemografiske variable, for på den måten å rendyrke effekten av flytning. Undersøkelsen var lagt opp som en case-control studie, der 1105 pasienter fra Sentralregisteret ble parvis matchet med hensyn til alder, kjønn, yrke, sivil stand og bopel innen Oslo i et materiale trukket fra Valgmanntallet for 1953. Begge populasjoner ble så kartlagt med hensyn til tidligere flytninger, og de relative innleggelsestall for de ulike flytningskategorier ble beregnet. I motsetning til de tidligere omtalte undersøkelser fant en da at innflytterne til Oslo hadde en lavere innleggelseshyppighet enn de Oslo-fødte. Det mest interessante funn var imidlertid at betydningen av flytning syntes å være avhengig av vedkommendes sosiale status. Mens innflyttere med lav sosial status hadde en lavere innleggelseshyppighet enn de med lav status som var født i Oslo, var det motsatte tilfelle for de med høy status. Det ble antatt at dette kunne henge sammen med sosial mobilitet, dvs. endring av sosial status i forhold til foreldrenes status. Dette ble bekreftet når en innhentet tilleggdata om farens yrkesmessige status. Det viste seg da at både oppadgående og nedadgående sosial mobilitet var knyttet til økt hyppighet av innleggelser (10). At nedadgående sosial mobilitet, som var vanligst blant folk med lav sosial status som var født $\mathrm{i}$ Oslo, var knyttet til øket hyppighet av psykoser, var ikke særlig overraskende. Her er det rimelig å anta at seleksjonsfaktorer gjør seg sterkt gjeldende. At oppadgående sosial mobilitet, som var vanligst blant innflyttere til Oslo med høy status, var imidlertid overraskende. Tatt i betraktning at oppadgående sosial mobilitet særlig var knyttet til manisk/depressiv psykose, var det imidlertid mulig at også dette kunne henge sammen med seleksjon, i det personer med hypomane personlighetstrekk kunne tenkes å være disponert både for psykoser og oppadgående sosial mobilitet. Det ble imidlertid antatt at den økede innleggelseshyppighet ved oppadgående sosial mobilitet også kunne henge sammen med stress i tilkytning til skifting av status og sosialt miljø (status-inkonsistens).

\section{Utdannelse}

I en undersøkelse av forholdet mellom utdannelse og innleggelse for psykose, igjen med utgangspunkt i Sentralregisteret, fant Ødegaard (11), og senere Noreik 
og Ødegaard (12), at det var interessante forskjeller mellom de to kjønn. Mens menn med høyere utdannelse hadde litt lavere innleggelseshyppighet enn totalbefolkningen, var forholdet omvendt for kvinner. For begge kjønn var det imidlertid en øket hyppighet av innleggelse for manisk/depressiv psykose. Når forfatterne supplerte de statistiske data med journalgjennomgåelser, fant de at seleksjonsfaktorer antakelig spilte en rolle for den økede innleggelseshyppighet av kvinner med høy utdannelse, som i det aktuelle tidsrom hadde vært en forholdvis liten gruppe. Men en antok også at stress i tilknytning til arbeid kunne være av betydning. For øvrig fant forfatterne at personer med høy utdannelse som hadde fedre med forholdsvis lav utdannelse hadde en høyere innleggelseshyppighet enn der hvor begge generasjoner hadde høy utdannelse. Som Dalgards undersøkelse (9) kan dette passe med at også oppadgående sosial mobilitet kan øke risikoen for psykose.

\section{Yrke}

Når det gjelder yrke, fant Ødegaard (13) at de med lavstatusyrker, som hadde lite utdanning og som var dårlig avlønnet, hadde den største hyppighet av førstegangsinnleggelser for psykose, igjen basert på tall fra Sentralregisteret. Dette kom særlig klart fram når en sammenliknet grupper fra samme arbeidssted med ulik yrkesmessig status. Således fant han at gårdsarbeidere hadde større innleggelseshyppighet enn bønder, vanlige sjømenn større hyppighet enn offiserer, ufaglærte arbeidere større hyppighet enn håndverkere og teknikere, og underordnede på kontor større innleggelseshyppighet enn overordnede og selvstendig næringsdrivende. Selv om en del av disse forskjeller kunne forklares ved andre sosiodemografiske variable, som sivil stand, viste undersøkelsen i hovedtrekk at innleggelseshyppigheten for sinnssykdom øket med avtakende yrkesmessig status. Igjen var det imidlertid vanskelig å si noe om årsaksforholdene - både seleksjon og stress kunne spille en rolle.

I en undersøkelse basert på førstegangsinnleggelser i psykiatriske klinikkavdelinger i Oslo, som omfattet både psykoser, nevroser og sinnslidelser knyttet til alkohol- og stoffmisbruk, fant også Sundby og Nyhus (14) en sammenheng mellom lav yrkesmessig status og øket hyppighet av innleggelse. De festet seg imidlertid spesielt ved at hyppigheten var særlig stor i yrker som var forbundet med ustabilitet med hensyn til arbeidstid og arbeidssted, slik som hos yrkessjåfører, serveringspersonale i restauranter, handelsreisende og sjøfolk. Mens schizofreni var hyppigst i lavstatusyrker, var innleggelse for affektive lidelser hyppigst i høystatusyrker. For øvrig var forfatterne også interessert $i$ betydningen av hvor i Oslo en bodde, og fant da som forventet ut fra den yrkesmessige fordeling at de sentrale lavstatusområder hadde størst innleggelseshyppighet. Når det gjelder forklaringsmekanismer, la forfatterne størst vekt på seleksjonsfaktorer.
Mens data fra Sentralregisteret var personidentifiserbare, og i alle fall i prinsippet omfattet alle innleggelser i psykiatriske sykehus og alle innleggelser av psykotiske pasienter i klinikkavdelinger, har en siden 1979 også hatt registreringer av alle voksne psykiatriske døgnpasienter på en bestemt dag hvert 5 . år. Disse data er imidlertid ikke personidentifiserbare, slik at en ikke kan følge pasienten over tid. Som nærmere omtalt i en egen artikkel i dette tidsskrift (15), har disse data $i$ første rekke blitt brukt til helsetjenesteforsking, og vært et meget verdifullt hjelpemiddel når det gjelder å følge utviklingen over tid innen det psykiske helsevern. Sentralregisteret ble nedlagt i 1988 da en fant at personidentifiserbare data var en trussel mot personvernet.

\section{UNDERSØKELSER HOVEDSAKELIG BASERT PÅ DATA FRA PRIMERLEGER}

Psykiatrisk epidemiologi basert på sykehusinnleggeser har som nevnt den begrensning at den bare omfatter de alvorligste psykiske lidelser. Et annet problem er at tendensen til innleggelse påvirkes av ulike faktorer i tillegg til lidelsens alvorlighetsgrad, ikke minst tilgangen på psykiatriske sengeplasser der en bor. Dette betyr blant annet at det med utgangspunkt i innleggelser blir problematisk å sammenlikne hyppigheten av sinnslidelser i ulike deler av landet. Tatt i betraktning at også en økende andel av psykosene etter hvert blir behandlet utenfor institusjon, er det behov for å skaffe data utover sykehusinnleggelser for å anslå den reelle hyppighet av ulike sinnslidelser i befolkningen. En slik supplerende datakilde er primærhelsetjenesten, som de fleste mennesker har kontakt med i løpet av et par år. Det knytter seg imidlertid også betydelige problemer til primærhelsetjenesten som datakilde, da det er høyst variabelt $\mathrm{i}$ hvor stor grad primærlegen diagnostiserer psykiske lidelser. Ved slike undersøkelser må en derfor ta utgangspunkt i leger som er særlig interessert i psykiske lidelser, og som er i stand til å diagnostisere disse på en noenlunde pålitelig måte. Eventuelt må en supplere undersøkelsen med spesielle spørreskjema som muliggjør identifisering av psykiske lidelser blant pasientene. I det følgende skal vi se på noen slike undersøkelser, som først og fremst har sin betydning ved den store forekomst av psykiske lidelser som er blitt avdekket i befolkningen.

Bremer (16) har gjort en omfattende kartlegging av psykiske lidelser i befolkningen fra den tid han var distriktslege i et lite fiskersamfunn i Finnmark (19391944). Basert på meget grundig kjennskap til befolkningen over lang tid er det grunn til å tro at resultatene gir et temmelig fullstendig bilde. På denne måten er undersøkelsen antakelig den første $\mathrm{i}$ verden som beskriver den totale psykiatriske morbiditet $i$ et avgrenset geografisk område, og som Ødegaards emigrasjonsundersøkelse tilhører den klassikerne innen internasjonal psykiatrisk epidemiologi. Undersøkelsen gir livstidsprevalens for psykoser og psykisk utviklings- 
hemning (oligofreni) og 5 års prevalens for nevroser og psykopati. Den samlede prevalens var $28,4 \%$, fordelt på følgende diagnoser: Psykoser: 3,6\%, nevroser: 9,9\%, psykopati: 9,4\% og oligofreni: 5,6\%. Blant psykosene var schizofreni den hyppigste, med en prevalens på $1 \%$. Når forfatteren delte befolkningen $\mathrm{i}$ to grupper etter sosial status, basert bl.a. på inntekt, sysselsetting og sosial hjelp fra det offentlige, fant han betydelig flere med psykiske lidelser i lavstatusgruppen. Dette hang sammen med at de fleste oligofrene befant seg i denne gruppen, som også hadde et betydelig innslag av "viljesvake psykopater". Spesielt forbigående nevroser fant en mest av i høystatusgruppen. Bremer la hovedvekten på seleksjon som forklaring på den sosiale skjevfordeling av psykiske lidelser, og mente at denne skyldtes en spesiell problemgruppe som i tilknytning til visse "mentale defekter" hadde problemer med å tilpasse seg så vel arbeid som familieliv, og med betydelig innslag av kriminalitet og alkoholmisbruk. Selv om det kan være delte meninger om tolkningen av Bremers funn, er det interessant at hans prevalenstall når det gjelder psykiske lidelser samsvarer godt med det en har funnet i senere befolkningsundersøkelser.

En annen omfattende kartlegging av psykiske lidelser basert på praksis som distriktslege, ble gjort av Bentsen (17), som i en Østlandskommune beskrev befolkningens totale helse, inklusive psykiske lidelser, over en 4-års periode (1952-55). Han fant en prevalens for psykiske lidelser totalt på $21,7 \%$, som fordelte seg slik etter alvorlighetsgrad: Alvorlig syke: $0,8 \%$, moderat syke: $6,0 \%$ og lite alvorlig syke: $14,9 \%$. Et interessant funn var at bare en fjerdedel av de psykiatrisk syke hadde vært syke i mer enn ett år, og omtrent 50\% av sykdomsepisodene hadde vart i mindre enn 4 uker. Bentsens vektlegging av episoder, til forskjell fra mer varige sykdommer, peker for øvrig fremover mot dagens klassifisering av psykiske lider i primærhelsetjenesten, der inndeling etter "reaksjoner" snarere enn "diagnoser" er karakteristisk.

At psykiske lidelser er svært utbredt blant pasienter i primærhelsetjenesten, blir også bekreftet av Øgar (18). I en kartlegging av psykiske lidelser blant pasientene hos et utvalg primærleger, fant han en total prevalens (tilnærmet punktprevalens) på $31 \%$, der nevroser var den største gruppen $(15,1 \%)$. I motsetning til Bremers og Bentsens undersøkelser kan en imidlertid ikke fra denne trekke direkte slutninger om prevalensen av psykiske lidelser i befolkningen.

Også med utgangspunkt i praksis fra primærhelsetjenesten, men supplert med data fra semi-strukturerte intervjuer, epikriser fra sykehus, spesialistuttalelser og informasjon fra nøkkelpersoner, gjorde Andersen (19) i perioden 1968-69 en omfattende undersøkelse over psykiske lidelser i to kulturelt kontrasterende lokalsamfunn, nemlig et samisk, med delvis fastboende og delvis nomadiserende befolkning, og et norsk fiske- og jordbrukssamfunn. Han fant en livstidsprevalens for psykiske lidelser totalt på $20,7 \%$ i det norske lokal- samfunn og 14,8\% i det samiske. Mens nevroser var mest utbredt i det norske samfunn, spesielt blant kvinner, var det tilsynelatende små forskjeller når det gjaldt psykoser. Her viste det seg imidlertid at det var forbundet med betydelige vanskeligheter å diagnostisere psykose $\mathrm{i}$ den samiske befolkningen, og forfatteren støtte på en del tilsynelatende kulturspesifikke reaksjoner hos samene, med angst og synshallusinasjoner, som var vanskelige å klassifisere. Andersen var meget forsiktig når det gjaldt forklaring av den relativt store hyppighet av nevroser blant de norske kvinnene, men antyder at psykiske symptomer kan ha en annen betydning som kommunikasjonsmiddel blant de norske enn blant samene.

\section{BEFOLKNINGSUNDERSØKELSER HOVEDSA- KELIG BASERT PÅ SPØRRESKJEMA ELLER STRUKTURERT INTERVJU}

Etter hvert ble det vanligere å basere psykiatriske befolkningsundersøkelser hovedsakelig på strukturerte intervjuer eller spørreskjema, med mindre innslag av klinisk intervju og data fra helsetjenesten. En fordel ved denne metodikk var øket reliabilitet, da den var mindre avhengig av den enkelte intervjuers kvalifikasjoner og subjektive vurdering. På den andre siden kunne en sette spørsmålstegn ved validiteten, i det en mistet en del informasjon som ligger i sammenfatningen av ulike data $i$ en diagnose. Et annet problem er at de med alvorlige sinnslidelser unndrar seg slike befolkningsundersøkelser, som vist av Hansen et al. (20). I en kartlegging av befolkningens helse i Tromsø, fant forfatterne nemlig at de som tidligere hadde vært innlagt for en alvorlig sinnslidelse i mindre grad enn andre hadde møtt opp til undersøkelsen. Det samme gjaldt de med alkohol- og stoffmisbruk. Dette betyr at de tall for psykiske lidelser som en får ved slike befolkningsundersøkelser er minimumstall, og ikke like representative for alle diagnosegrupper.

Andersens tidligere omtalte undersøkelse (19) var på mange måter inspirert av Leightons og medarbeideres undersøkelser i Nigeria og Canada (21), der en hadde samlet inn opplysninger gjennom ulike kilder, bl.a. helsetjenesten, men hvor et strukturert, symptomorientert intervju spilte en sentral rolle. Med utgangspunkt i en forkortning av dette, foretok Dalgard (22) en større befolkningsundersøkelse i Oslo. Materialet omfattet vel 1000 voksne personer som var tilfeldig trukket ut fra ulike typer bomiljøer i Oslo i 1974, og ca. 60 personer, for det meste legestudenter og helsepersonell, foretok intervjuene. Forekomsten av psykiske lidelser totalt, hovedsakelig angst og depresjon, var på intervjutidspunktet 19,9\%, mens livstidsprevalens var $25,6 \%$. Det mest interessante funn var forskjellene i psykisk helse mellom de ulike typer bomiljøer. Den høyeste aktuelle prevalens av psykiske lidelser (29\%) fantes $i$ en ny drabantby, mens den laveste prevalens fantes i vel etablert villabebyggelse (9\%). Den eldre bykjerne kom i en mellomstilling. Dette fordelings- 
mønster holdt seg stort sett uforandret når en kontrollerte statistisk for en rekke variable, som kjønn, alder, sivil stand, inntekt, utdannelse og flytningestatus. I likhet med Leighton fant Dalgard en sammenheng mellom øket hyppighet av psykiske lidelser og sosial desintegrasjon, da det var typisk for den nye drabantbyen at befolkningen der var lite stabil, at de sosiale nettverk var relativt dårlig utviklet og at forholdene var dårlig tilrettelagt for rekreasjon, kontakt og samhandling. Han trakk da den konklusjon at selv om de som bosatte seg i den nye drabantbyen hadde flere psykiske og sosiale problemer før de flyttet inn, bidro miljøet til en klar forverring, der folk med relativt dårlig nettverk ble utsatt for relativt mye påkjenninger. Ved en oppfølging av det samme materiale etter 10 år (23), viste det seg at forholdene hadde forbedret seg betydelig $\mathrm{i}$ den nye drabantbyen, blant annet som følge av en rekke positive miljøtiltak, samtidig som folks psykiske helse var blitt signifikant bedret. Alt i alt trekker da dette i retning av at et dårlig bomiljø bidrar til utvikling av psykiske lidelser, noe som er interessant ikke minst i tilknytning til forebyggende helsearbeid.

Med tilsvarende metodikk gjorde Sørensen (24) en undersøkelse i en typisk pendlerkommune og en stabil jordbrukskommune på Østlandet. Han fant da at hyppigheten av psykiske lidelser var størst i pendlerkommunen, noe som hang sammen med at ikke bare pendlerne og deres familie, men også befolkningen for øvrig i denne kommunen hadde relativt dårlig psykisk helse. Disse forskjeller kunne ikke forklares gjennom de vanlige sosiodemografiske variable, og i tråd med Leighton og Dalgard konkluderte Sørensen med at sosial desintegrasjon antakelig spilte en rolle. Pendlerkommunen var nemlig preget av en svakere sosial integrasjon enn den stabile jordbrukskommunen, med svakere sosiale nettverk og mindre sosial samhandling, noe som igjen kunne henge sammen med at en betydelig del av den arbeidsføre mannlige befolkning bare tilbrakte en begrenset tid i hjemstedskommunen.

Også når det gjelder barn og ungdom har det vært gjort omfattende epidemiologiske undersøkelser i Norge. Den mest kjente er utført av Lavik (25), som i 1973 sammenliknet den psykiske helse blant 15-16 år gamle ungdommer fra fire skoler i Oslo og to skoler i en bygdekommune på Østlandet. Opplysningene ble dels innhentet gjennom semistrukturerte intervjuer og spørreskjema til elevene, dels gjennom intervju av elevenes klasseforstander. Hovedfunnet var at hyppigheten av psykiske lidelser og atferdsforstyrrelser var langt høyere i Oslo, spesielt blant gutter, enn i landkommunen. Mens prevalenstallene for Oslo var henholdsvis $23,1 \%$ og $15,9 \%$ for gutter og jenter, var tallene for landkommunen henholdsvis 7,7\% og 8,2\%. Blant guttene, spesielt de i Oslo, var atferdsforstyrrelser dominerende, mens det blant jentene var angst, depresjon og psykosomatiske plager som dominerte. De som hadde fedre med lav yrkesmessig status hadde mest psykiske lidelser, og dette gjaldt både i Oslo og landkommunen. Det var imidlertid ingen signifikant forskjell mellom de ulike skolene i Oslo, selv om disse representerte ulike sosiale miljøer.

En annen omfattende undersøkelse av den psykiske helse blant barn og unge ble gjort av Kolstad (26) i Sogn og Fjordane i perioden 1976-77. Data ble innhentet på forskjellige måter, fra leger, lærere og fra de unge selv, og de dekket ulike aldersgrupper. Da en brukte samme inndeling etter psykisk helse som Lavik hadde brukt, er resultatene tilnærmet sammenliknbare, selv om data var innhentet på litt forskjellig måte. Et hovedfunn var at hyppigheten av psykiske lidelser blant barn og unge i Sogn og Fjordane var vesentlig lavere enn i Oslo, i det hyppigheten av betydelige plager eller atferdsforstyrrelser var 4,3\% i Sogn og Fjordane mot 19,6\% i Oslo. Prevalenstallene for Vestlandsfylket var også lavere enn for landkommunen på Østlandet i Laviks undersøkelse. Mens det også i Kolstads undersøkelse var størst hyppighet av atferdsforstyrrelser hos guttene, og mest angst, depresjon og psykosomatiske plager hos jentene, var det ikke slik som i Oslo at guttene totalt sett hadde mest psykiske problemer. Også forskjellig fra Laviks undersøkelse fant ikke Kolstad noen signifikant sammenheng mellom sosial status hos fedrene og barnets psykiske helse. Derimot fant han en sammenheng mellom begynnende urbanisering, ustabilitet og mangel på sosial integrasjon i lokalsamfunnet og psykiske problemer blant barn og ungdom. Alt $i$ alt trakk han da den konklusjon at den relativt lave hyppighet av psykiske problemer blant barn og ungdom i Sogn og Fjordane henger sammen med at det her stort sett dreier seg om stabile lokalsamfunn med en befolkning som opplever stor grad av forankring og tilhørighet.

Mens de undersøkelser som er omtalt ovenfor, der data ble innhentet gjennom forholdvis omfattende spørreskjema og strukturerte intervjuer, var relativt tidog kostnadskrevende, begynte en etter hvert å ta i bruk mer kortfattede symptomskalaer, ofte kalt "screeninginstrumenter". Disse spørreskjemaene ga ikke grunnlag for å stille psykiatriske diagnoser, men tok stort sett sikte på å måle plager av mer generell karakter. Symptomer på angst og depresjon var gjerne fremtredende, og disse ble oppfattet som uttrykk for "distress". Ved senere undersøkelser (27) viste det seg at forekomsten av psykiatriske case basert på et screeninginstrument var omtrent den samme som ved et standardisert klinisk intervju, men det var ikke nødvendigvis de samme case som ble identifisert. Selv om dette skaper en viss usikkerhet om screeninginstrumentenes validitet, muliggjør disse symptomskalaer en langt raskere og enklere gjennomføring av befolkningundersøkelser enn de som er basert på intervju. Ikke minst med tanke på oppfanging av endringer i befolkningens psykiske helse over relativt kort tid, kan dette være en fordel.

Statistisk Sentralbyrå var tidlig ute med bruk av psykiatriske symptomskalaer i sine landsomfattende helseundersøkelser, og tok da utgangspunkt i Hopkins Symptom Checklist -25 (HSCL-25), som omfatter 25 
spørsmål om angst, depresjon og somatisering. (To spørsmål ble utelatt, slik at det i virkeligheten dreidde seg om HSCL-23). Med utgangspunkt i konvensjonelle skårings-regler kunne en da identifisere såkalte case i befolkningen. Resultatene fra helseundersøkelsen i 1985 er beskrevet av Moum og medarbeidere (28) i 1991. Det viste seg da at tallene for psykiske plager var adskillig lavere enn det en kunne forvente fra andre undersøkelser, i det hyppigheten av psykiske plager blant menn var bare $1,1 \%$ og blant kvinner $4,5 \%$. Dette er jo blant annet mye lavere tall enn det en fant i SSBs helseundersøkelse i 1998, og som er beskrevet i dette tidsskrift (29). Senere har en kommet til at de lave tall fra undersøkelsen i 1985 hang sammen med at en den gang presenterte HSCL-25 som et muntlig intervju, mens instrumentet er ment å være selvutfyllende, dvs. at det fylles ut av respondenten uten noen andre til stede. Også noe overraskende fant en ingen klar sammenheng mellom yrkesmessig status og psykisk helse, mens det var en tendens til at tidligere gifte hadde øket hyppighet av psykiske plager sammenliknet med gifte og aldri gifte.

I en spørreskjemaundersøkelse i Nord-Norge i 1983/84 kartla Sørensen den psykiske helse i befolkningen ved hjelp av HSCL-25 (30). Han fant små geografiske forskjeller både når han sammenliknet ulike kommuner i Nord-Norge, og når han sammenliknet med nye tall fra de kommuner på Østlandet som han tidligere hadde undersøkt (24). Hyppigheten av psykiske plager var ca. $9 \%$ hos menn og ca. $20 \%$ hos kvinner. Det var en klar tendens i retning av mest symptomer hos tidligere gifte og de med lav yrkesmessig status. Mest utsatt var imidlertid de som i løpet av siste 12 måneder hadde vært utsatt for negative livshendelser. De livshendelser som slo sterkest ut var alvorlig sykdom hos en selv, økonomiske problemer og problemer i ekteskapet. Undersøkelsen inngikk i planleggingen av det psykiske helsevern i de undersøkte kommuner, og forfatteren fremhevet i sin konklusjon betydningen av et utadrettet psykisk helsevern, der en både når det gjaldt behandling og forebygging tok sikte på å møte folk i deres aktuelle livssituasjon.

Med særlig fokus på forebyggende arbeid ble det ved Senter for sosialt nettverk og helse (et prosjekt under Helsedirektoratet) utført en rekke befolkningsundersøkelser i perioden 1990-95, der en hovedsakelig brukte HSCL-25 som mål på psykisk helse (31). "Kommunediagnose", eller "helseprofil i lokalsamfunnet", var sentrale begreper i denne forskingen, der en snarere tok sikte på å kartlegge kjente risiko- og beskyttelsesfaktorer i befolkningen med sikte på forebyggende og helsefremmende arbeid, enn å identifisere nye årsaksforhold (32). Unntak fra dette var imidlertid en serie longitudinelle undersøkelser, der en kunne teste hypoteser om årsakssammenhenger. Således gjorde Mathiesen (33) en oppfølging av et materiale på ca. 1000 småbarn innhentet gjennom Helsestasjonene, for å avdekke prediktorer for senere tilpasningsvansker, mens Ystgaard (34) gjorde en oppfølgingsunder- søkelse av skoleungdom for å evaluere effekten av en antatt forebyggende intervensjon, og for å se på samspillet mellom negative livshendelser, sosial støtte og psykisk helse. Samspillet mellom sosial støtte og negative livshendelser ble også undersøkt i en 10-års oppfølging av Dalgards Oslo-materiale (35), der en fant at betydningen av negative livshendelser ikke bare var avhengig av sosial støtte, men også av individets attribuerings-stil (locus of control). Også i forbindelse med noen av helseprofils-undersøkelsene, ble det foretatt oppfølginger etter et visst antall år. Den mest omfattende longitudinelle undersøkelsen ble gjort av Brevik, som kunne påvise en negativ effekt på den psykiske helse hos de som var blitt tvangsflyttet $i$ forbindelse med utbyggingen av flyplassen på Gardermoen $(36,37)$, og også en sannsynlig positiv effekt av miljørettede forebyggende tiltak rettet mot denne risikogruppen.

Av andre epidemiologiske undersøkelser med bruk av spørreskjema kan nevnes Claussens undersøkelse (38) av den psykiske (og somatiske) helse hos langtids arbeidsledige i tiden 1988-90. Ved sammenlikning av forekomsten av psykiske plager hos et representativt utvalg arbeidsledige med forekomsten blant arbeidstakere fra Statistisk Sentralbyrås tidligere omtalte landsomfattende undersøkelse (28), fant han en øket hyppighet av plager blant de arbeidsledige, og mest hos de som ved oppfølging to år senere fortsatt var uten arbeid. På grunn av de feilaktige lave tall for HSCL-25 fra undersøkelsen i 1985 (kfr. tidligere), blir imidlertid denne sammenlikningen usikker. Imidlertid fant han ved en senere sammenlikning med tallene fra Oslo/Lofoten undersøkelsen (kfr. senere) at det fortsatt var øket hyppighet av psykiske plager hos de arbeidsledige, spesielt hos menn.

Senere er det foretatt også en rekke andre psykiatriske befolkningsundersøkelser i Norge med bruk av spørreskjema, blant annet i Nord-Trøndelag (HUNT) og Hordaland (HUSK), i Statens Helseundersøkelser av 40-åringer og i Statististisk Sentralbyrås landsomfattende helseundersøkelse i 1998.

\section{UNDERSØKELSER BASERT PÅ STANDARDI- SERTE KLINISKE INTERVJU}

I tråd med utviklingen internasjonalt, har det $\mathrm{i}$ de senere psykiatriske befolkningsundersøkelser i Norge blitt vanlig å bruke standardiserte kliniske intervjuer, til dels etter en første screening med spørreskjema. Slike undersøkelser er tidkrevende og kostbare, men gir et mer nyansert bilde av den psykiatriske morbiditet enn undersøkelser basert på spørreskjema eller strukturerte intervju, og er mer egnet til å skape gjenkjennelse hos klinikerne.

Den første av disse var en større undersøkelse fra et utvalg kommuner i Lofoten og en ny bydel i Oslo, Søndre Nordstrand (39). Over 2000 tilfeldig utvalgte voksne personer ble intervjuet med henblikk på psykisk helse og en rekke sosiale og psykososiale 
forhold. De som skåret høyt på HSCL-25, samt et utvalg av de som skåret lavt, ble intervjuet med CIDI (Composite International Diagnostic Interview). Med hensyn til depresjon, angst og somatoforme lidelser fant Sandanger og medarbeider en samlet to-ukers prevalens på 21,5\% hos kvinner og $11,5 \%$ hos menn. Et annet hovedfunn var at hyppigheten av nye tilfelle (insidens), basert på intervjuobjektenes opplysninger om når de første gang ble syke, viste en sterkt stigende tendens i løpet av de senere tiår, spesielt for depresjon. Dette kan henge sammen med dårlig hukommelse for det som hendte lang tid tilbake, men når tendensen også holdt seg for de siste årene, tyder resultatene på at det faktisk har skjedd en økning i insidens, spesielt for depresjon, i løpet av den senere tid. Dette er i så fall i samsvar også med undersøkelser fra andre land, som Sverige og USA. For øvrig ga undersøkelsen grunnlag for en nærmere diskusjon av forholdet mellom case basert på HSCL-25, og case basert på CIDI, noe som blir omtalt i en egen artikkel i dette tidsskrift (40). Det er nå foretatt en 10-års oppfølging av dette materialet, og analyse av data pågår.

I en epidemiologisk undersøkelse av depresjon i 5 ulike Europeiske land, ODIN (Outcome of Depression in Europe), inngikk Norge sammen med Finland, Irland, Storbritannia og Spania (41). I denne undersøkelsen, som fant sted i 1996-1997, gjorde en først en screening med bruk av BDI (Beck Depression Inventory), og intervjuet deretter de som skåret høyt på dette instrument, samt et mindre utvalg av de som skåret lavt, med det standardiserte klinisk intervju SCAN II (Schedule for Clinical Assessment in Neuropsychiatry). Når en sammenliknet de byene som inngikk i undersøkelsen (Oslo, Turku, Liverpool, Dublin og Santander), fant en for Oslo en 4-ukers prevalens for depresjon på $8,8 \%$ (12,0\% for kvinner og 5,6\% for menn). Dette var omtrent det samme som for Turku, men betydelige høyere enn for Santander $(2,6 \%)$ og betydelig lavere enn for Dublin $(12,3 \%)$ og Liverpool $(17,1 \%)$. For øvrig dannet ODIN-undersøkelsen utgangspunkt for utprøving av en psyko-edukativt basert intervensjon for et randomisert utvalg av de som var blitt diagnostisert som depressive, med påfølgende oppfølging av både intervensjons- og kontrollgruppe. For så vidt var dette et eksempel på eksperimentell epidemiologi.

En tredje større epidemiologisk undersøkelse, basert på standardisert klinisk intervju, er utført av Kringlen, Torgersen og Cramer i årene 1994-1997 (42,43). I denne undersøkelsen intervjuet en ca. 2000 tilfeldig utvalgte voksne fra henholdvis Oslo og Sogn og Fjordane, og alle ble gjenstand for et standardisert klinisk intervju (CIDI). Bare data fra Oslo er publisert, og en rapporterte da meget høye prevalenstall for psykiatriske lidelser totalt, nemlig $32,8 \%$ for 12 -måneders prevalens og 52,4\% for livstidsprevalens. 12-månders prevalens av depresjon (major depression og dysthymia) i Oslo var $11,1 \%$, hvilket svarer godt til tallene fra ODIN-undersøkelsen. Tallene er ellers omtrent i samsvar med det en har funnet i USA med tilsvarende metodikk. Personlighetsforstyrrelser ble diagnostisert med Structured Interview for DSM-III Personality Disorder (SIDP-R), og en fant da en prevalens på 13,4\%. Personlighetsforstyrrelse forekom ofte i kombinasjon med annen psykiatrisk lidelse. Hyppigheten av psykiatriske lidelser totalt var størst hos kvinner, hos de med lite utdannelse og hos de som bodde i de eldre sentrale bydeler av Oslo, og den var også klart større i Oslo enn i Sogn og Fjordane (44).

\section{KONKLUSJON}

Norge har en lang og rik tradisjon når det gjelder psykiatrisk epidemiologi, og utviklingen har fulgt de samme linjer som vi finner internasjonalt: fra enklere deskriptive studier av de alvorligste sinnslidelser til analytiske og longitudinelle studier av hele spekteret av psykiske lidelser.

En medvirkende årsak til den betydelige innsats når det gjelder psykiatrisk epidemiologi $i$ vårt land, er den relativt stabile og oversiktlige befolkning, som gjør det forholdsvis lett å foreta kartlegginger og følge befolkningen over tid. En annen årsak er pålitelig offentlig statistikk og tilgang til pasientregistere. Når det gjelder det siste kommer Sentralregisteret for sinnssyke i en særstilling, og det var et betydelig tap for fagfeltet da dette ble nedlagt i 1988. En tredje årsak kan være at den epidemiologiske forsking til dels har skjedd i nært samspill med den kliniske og administrative psykiatri, og på den måten bidratt med resultater som kan være nyttige for psykiatrisk praksis og planlegging av det psykiske helsevern. Ikke minst gjennom den forskning som tok utgangspunkt i Sentralregisteret, fikk en data som bygget opp under sosialpsykiatrisk virksomhet, ved å rette oppmerksomheten mot sosiale årsaksfaktorer. Pasientregistreringen gjennom SINTEF (15) har vært et viktig hjelpemiddel i planleggingen av det psykiske helsevern. I de senere år har psykiatriske befolkningsundersøkelser dannet utgangspunkt for forebyggende arbeid og behandlingsmessige tiltak, og disse undersøkelsene har ikke minst spilt en viktig mentalhygienisk rolle ved å alminneliggjøre de psykiske lidelser.

Det er viktig at tradisjonen i psykiatrisk epidemiologi i vårt land blir ført videre, og i så måte er det gledelig at det $\mathrm{i}$ dag finnes en rekke forskningsmiljøer i Norge der psykiatrisk epidemiologi er en viktig del. Som det fremgår av dette tidsskrift, drives det psykiatrisk epidemiologisk forsking en rekke steder $\mathrm{i}$ landet, og det er mange spennende prosjekter på gang. Også innen barnepsykiatrien har interessen for epidemiologisk forskning vært stigende, og også her er det nå et stort antall epidemiologiske prosjekter på gang. En viktig forutsetning for denne ekspansjon har vært økede midler til psykiatrisk forsking gjennom Norsk forskningsråd, Rådet for psykisk helse og nå sist, Stiftelsen for helse og rehabilitering. 
Med tanke på den videre utvikling av fagfeltet, er det viktig at en får adgang til pålitelige data både når det gjelder de alvorlige og mindre alvorlige sinnslidelser og psykiske plager. Dette forutsetter data både fra den spesialiserte psykiatriske helsetjeneste, primærhelsetjenesten og befolkningsundersøkelser. Ikke minst med tanke på den opptrapping som nå skjer innenfor det psykiske helsevern, er det viktig å ha tilgang til data fra dette felt, både av hensyn til planlegging og evaluering. Når det gjelder spesialisthelsetjenesten, har en som omtalt av Ruud (29) i løpet av de siste årene utviklet et "minste basis datasett" som skal dekke alle pasienter som har kontakt med det psykiske helsvern. Når dette blir tatt i bruk av det samlede psykiske helsevern, vil det kunne spille en viktig rolle også når det gjelder epidemiologisk forskning. Disse data er imidlertid bare personidentifiserbare innenfor den enkelte institusjon, slik at de i motsetning til Sen- tralregisteret ikke kan gi grunnlag for landsomfattende epidemiologisk forskning, der en også kan følge pasientene over institusjonsgrenser. Det er å håpe at dette kan endres i fremtiden, slik at en igjen får et landsomfattende register med personidentifiserbare data. Moderne teknologi skulle gjøre det mulig å forene et slikt register med de nødvendige personvernhensyn.

Når det gjelder kartlegging av den psykiske helse i videste forstand, er det positivt at Statistisk Sentralbyrå i sine landsomfattende Helse- og levekårsundersøkelser nå vil øke mengden av data når det gjelder psykiske lidelser og psykososiale problemer. Med dette vil en blant annet få bedre sammenlikningsgrunnlag for andre undersøkelser, få bedre mulighet til å følge befolkningens psykiske helse over tid, kunne identifisere høy-risikogrupper som utgangspunkt for mer dyptgående undersøkelser, og også få mulighet til å sammenlikne med tilsvarende data fra andre Europeiske land.

\section{REFERANSER}

1. Beretning, Betænkning og Indstilling fra en til at undersøge de Sindssvages Kaar i Norge og gjøre Forslag til deres Forbering i Aaret 1825 naadigst nedsatt Kongelig Commision. I følge Kgl. Resol. Udgivet av Frederik Holst, M.D. Christiania: Jacob Lehmanns Enke, 1928.

2. Holst F. On the Statistics of the Insane, Blind, Deaf and Dumb, and Lepers, of Norway. Translated from Danish by A.S. Oliver Massy, Esq. Royal Statistical Society of London Journal 1852; 15: 250-256.

3. Dahl L. Bidrag til Kundskab om de Sindssyge i Norge. Christiania: Det Steenske Bogtrykkeri, 1859.

4. Ødegaard Ø. Emigration and insanity. Acta Psychiatr Neurol Scand 1932; Suppl 4.

5. Ødegaard Ø. The incidence of mental diseases as measured by census investigation versus admissions statistics. Psychiatr $Q$ 1952; 26: 212-218.

6. Eitinger L. Psykiatriske undersøkelser blant flyktninger $i$ Norge. Oslo: Universitetsforlaget, 1958.

7. Ødegaard Ø. The distribution of mental diseases in Norway. Acta Psychiatr Scand 1945; 20: 247-284.

8. Astrup C, Ødegaard Ø. Internal migration and mental disease in Norway. Psychiatr Q 1960; Suppl 34: 116130.

9. Dalgard OS. Migration and functional psychoses in Oslo. Oslo: Universitetsforlaget, 1967.

10. Dalgard OS. Status inconsistency and functional psychoses in Oslo. Acta Socio-Med Scand 1963; 1: 55-60.

11. Ødegaard Ø. Mental disease in Norwegians with high-school background. Acta Psychiatr Scand 1963; 39: 3140.

12. Noreik K, Ødegaard Ø. Psychosis in Norwegians with background of higher education. Br J Psychiatry 1966; 112: 43-55.

13. Ødegaard Ø. The incidence of psychosis in various occupations. Int J Soc Psychiatry 1956; 2: 85-104.

14. Sundby P, Nyhus P. Major and minor psychiatric disorders in males in Oslo. Acta Psychiatr Scand 1963; 39: 519-547.

15. Ruud T, Wessel Andersson H, Bjørngaard JH, Hagen H, Halsteinli V, Heggestad T, Pedersen PB. Forskning om bruk av psykisk helsevern i Norge. Norsk Epidemiologi 2002; 12 (3): 319-325.

16. Bremer J. Social psychiatric investigation of a small community in Northern Norway. Acta Psychiatr Scand 1951, Suppl 62.

17. Bentsen BG. Illness and general practice. Oslo: Universitetsforlaget, 1970.

18. Øgar B. Pasienter i norsk almenpraksis. Oslo: Universitetsforlaget, 1977.

19. Andersen T. Ill health in two contrasting communities (doktoravh.). Tromsø: University of Tromsø, 1978.

20. Hansen V, Jacobsen BK, Arnesen E. Prevalence of serious psychiatric morbidity in attenders and nonattenders to the health survey of a general population. The Tromsø Health Study. Am J Epidemiol 2001; 154: 891-894.

21. Leighton AH, Lambo TA, Hughes CC, Leighton DC, Murphy JM, Macklin DB. Psychiatric disorder among the Yoruba. New York: Cornell University Press, 1963.

22. Dalgard OS. Bomiljø og psykisk helse. Oslo: Universitetsforlaget, 1980. 
23. Dalgard OS, Tambs K. Urban environment and mental health. A longitudinal study. Br J Psychiatry 1997; 171: $530-536$.

24. Sørensen T. Miljø-skifte - psykiske lidelser. I: Medicinsk Årbog. København: Munksgaard, 1981: 137-144.

25. Lavik NJ. Ungdoms mentale helse. Oslo: Universitetsforlaget, 1976.

26. Kolstad A. Til diskusjon om sammenhengen mellom sosiale forhold og psykiske strukturer. En epidemiologisk undersøkelse blant barn og unge (doktoravh.). Aalborg: Universitetet i Aalborg, 1983.

27. Sandanger I, Moum T, Ingebrigtsen G, Sørensen T, Dalgard OS, Bruusgaard D. The meaning and significance of caseness. The Hopkin Symptom Checklist -25 and the Composite International Diagnostic Interview II. Soc Psychiatry Psychiatr Epidemiol 1999; 34: 53-59.

28. Moum T, Falkum E, Tambs K, Vaglum P. Sosiale bakgrunnsfaktorer og psykisk helse. I: Moum T, red. Helse i Norge. Sykdom, livsstil og bruk av helsetjenester. Oslo: Gyldendal, 1991: 47-63.

29. Rognerud M, Strand BH, Dalgard OS. Psykisk helse i Helse- og levekårsundersøkelsen i 1998. I. Sosioøkonomiske forskjeller i psykisk helse og livsstil. Norsk Epidemiologi 2002; 12 (3): 239-248.

30. Sørensen T. Mental helse i Nordkyst. Nordland Fylkeskommune, Fylkeshelsesjefen, 1987.

31. Dalgard OS, Døhlie E, Ystgaard M, red. Sosialt nettverk, helse og samfunn. Oslo: Universitetsforlaget, 1995.

32. Dalgard OS, Brevik JI, Hjemmen A. Helseprofil i lokalsamfunnet, med særlig vekt på sosiale risikofaktorer og psykisk helse. I: Dalgard OS, Døhlie E, Ystgaard M, red. Sosialt nettverk, helse og samfunn. Oslo: Universitetsforlaget, 1995: 126-143.

33. Mathiesen KS. Prediktorer for tilpasningsvansker hos førskolebarn. Barnas temperament, mødrenes psykiske helse og forhold i omgivelsene. Oslo: Statens institutt for folkehelse, 1999.

34. Ystgaard M, Tambs K, Dalgard OS. Life stress, social support and psychosocial distress in late adolescence: a longitudinal study. Soc Psychiatry Psychiatr Epidemiol 1999; 34: 12-19.

35. Dalgard OS, Bjørk S, Tambs K. Social support, negative life events and mental health - a longitudinal study. Br J Psychiatry 1995; 166: 29-34.

36. Brevik JI. Utbygging av Gardermoen. Menneske og miljø. Helsemessige konsekvenser av hovedflyplassutbyggingen. En delrapport. Oslo: Senter for sosialt nettverk og helse, Rapport Nr. 1/95, 1995.

37. Brevik JI. Helseundersøkelsen 2001. Helse og trivsel etter at flyplassen har kommet i ordinær drift. Ikke trykket rapport, 2002.

38. Claussen B. Deprived of work and health? A two year follow up of long term unemployed from Grenland, Norway, 1988-90. Oslo: Statens institutt for folkehelse, Research Report No. F 1-1994.

39. Sandanger I, Nygård JF, Ingebrigtsen G, Sørensen, T, Dalgard OS. Prevalence, incidence rate and age at onset of psychiatric disorders in Norway. Soc Psychiatry Psychiatr Epidemiol 1999; 34: 570-579.

40. Sandanger I, Nygård JF, Sørensen T. The concept of psychiatric illness - a core problem in psychiatric epidemiology. Norsk Epidemiologi 2002; 12 (3): 181-187.

41. Ayuso-Mateos JL, Vazquez-Barquero JL, Dowrick C, Lehtinen V, Dalgard OS, Casey P, Wilkinson C, Lasa H, Page H, Dunn G, Wilkinson G and the ODIN Group. Depressive disorders in Europe: prevalence figures from the ODIN study. Br J Psychiatryy 2001; 179: 308-316.

42. Kringlen E, Torgersen S, Cramer V. A Norwegian psychiatric epidemiological study. Am J Psychiatry 2001; 158: $1091-1098$.

43. Torgersen S, Kringlen E, Cramer V. The prevalence of personality disorders in a community sample. Arch Gen Psychiatry 2001; 58: 590-596.

44. Kringlen E. Personlig meddelelse, 2002. 